smokers endorsed ease of inhalation and ability to inhale more deeply as reasons for smoking menthol cigarettes. Such a pattern of smoking could contribute to excess disease risk. Several studies, however, indicate that menthol cigarette smokers inhale less frequently and less deeply than non-menthol cigarette smokers. ${ }^{4,5}$ Although additional data on this issue are desirable, it is possible that mentholation facilitates the absorption of tar, nicotine, and other products from cigarettes, ${ }^{4}$ while at the same time allowing smokers to smoke cigarettes in a more "soothing" way, fostering the perception that they can inhale easily and deeply.

It is not surprising that familial and social factors play a major role in choice of menthol over non-menthol cigarettes. Advertising dollars, no doubt, also play an important, albeit subtle, role. ${ }^{6}$ Given the widespread popularity of menthol cigarettes among African Americans, it is essential that putative excess adverse health effects of menthol cigarettes be determined and corrective action, if necessary, be undertaken

NORMAN HYMOWITZ CHARLES MOUTON HAFTAN EDKHOLDT New fersey Medical School Newark, New fersey, USA

This research was supported in part by Grant No. PHS-NHLBI 2R 44 HL42738-

- 02, subcontract to Norman Hymowitz.

1 Robinson RG, Pertschuck, M. Smoking and African Americans. In: Samuels SE, Smith $\mathrm{MD}$, eds. Improving the health of the poor. Menlo Park, California: Henry J Kaiser Family Foundation, 1992: 123-81.

2 Schmeltz I, Schlotzhauer WS. Benzo[a]pyrene, phenols, and other products from pyrolysis of the cigarette additive $(\mathrm{d}, 1)$-menthol. Nature 1968; 219: $370-1$.

3 Hebert JR, Kabat GC. Menthol cigarette smoking and esophageal cancer. Int $\mathcal{J}$ Epismoking and esophagea

McCarthy WJ, Caskey NH, Jarvik ME, et al. Menthol vs non menthol cigarettes: Effects on smoking behavior. Am $\mathcal{F}$ Public Health 1995; 85: 67-72.

5 Sidney S, Tekewa I, Friedman GD. Mentholated cigarette use among multiphasic examinees, 1979-86. Am $\mathcal{F}$ Public Health 1989; 79 : 1415-16.

6 Cummings KM, Giovino G, Mendicino AJ. Cigarette advertising and black-white differences in brand preference. Public Health Rep 1987; 102: 698-701.

$+$

\section{French cardiologists and smoking}

To the Editor - Interventions by physicians are recognised as having potential to convince many smokers to quit. ${ }^{1-3}$ In 1993 , a postal survey was undertaken among 2171 members of the French Society of Cardiology. Its aim was to assess attitudes and opinions of French cardiologists towards tobacco and then to

Percentage of French cardiologists answering "often" to the question: "In these three situations would you advise patients against smoking? Situation 1: When the patient has

symptoms/confirmed diagnosis of tobacco-related diseases. Situation 2: When the patient himself raises the question about smoking. Situation 3: When the patient is a smoker who has no symptoms/diagnosis of smoking-related diseases and doesn't himself raise the question of smoking."

\begin{tabular}{|c|c|c|c|c|}
\hline & $\begin{array}{c}\text { Daily smoker } \\
n=100\end{array}$ & $\begin{array}{c}\text { Occasional } \\
\text { smoker } \\
n=97\end{array}$ & $\begin{array}{c}\text { Ex-smoker } \\
n=341\end{array}$ & $\begin{array}{c}\text { Never-smoker } \\
n=192\end{array}$ \\
\hline $\begin{array}{l}\text { Situation } 1 \\
\text { Situation } 2 \\
\text { Situation } 3^{\star}\end{array}$ & $\begin{array}{l}99 \\
95 \\
54\end{array}$ & $\begin{array}{r}100 \\
98 \\
68\end{array}$ & $\begin{array}{l}99 \\
97 \\
68\end{array}$ & $\begin{array}{l}99 \\
97 \\
63\end{array}$ \\
\hline
\end{tabular}

$\star \mathrm{p}<0.05$. compare information with the results of a similar survey in a representative sample of French general practitioners. ${ }^{4}$ The questionnaire, which was designed by the World Health Organisation and the International Against Tuberculosis and Lung Dis(IUATL), was similar in the two surveys. A total of $730(33.6 \%)$ cardiologists responded to the mailing. There were no ignificant differences between non-responders by age, sex, and geographical location. The prevalence of smoking was $27 \%(14 \%$ daily smokers, $13 \%$ occasional smokers) \% among young cardiologists (age < 45) than among older ones $(33 \% v 21 \%)$. Smoking rates were similar in both sexes. Mean daily cigarette consumption was 9 (SD 8). Most smoked filter-tipped cigarettes. Of daily smokers, $42 \%$ claimed to have made they would stop within smokers)

Most $(97 \%)$ French cardiologists strongly dheir smoking status). They good knowledge of the adverse health 45 years were significantly better informed the risk of coronary disease and chronic bronchitis related to smoking than older cardiologists $(p<0.001)$. As shown in the table, French cardiologists have a differen according smoker's situation. Only $64 \%$ give who do not have tobacco-related disease and who do not raise a question about the dangers of tobacco; the proportion is lower in cardiolgists who are themselves daily smokers $(54 \%)$. Only $53 \%$ of cardiologists felt they nowledge to counsel patients health professionals should get training to help their smoking patients. A total of $36 \%$ disagreed with banning tobacco advertising, the highest proportion being in daily smokers (63\%). cardiologists $(14 \%)$ was lower than among French general practitioners $(21 \%) .{ }^{4}$ Our results for cardiologists confirm the lower

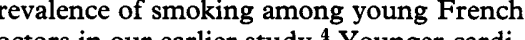
ologists also have a better knowledge of the adverse effects of smoking. But $37 \%$ of them do not systematically advise a smoking patient to quit. The proportion of cardiologists who need training on smoking cesstion methods is similar to that in general ractitioners.

Results of our survey are consistent with conclusions of a recent IUATLD survey among medical students ${ }^{5}$ and emphasize the agreed that smoking is harmful to health (in- need for reforms in the teaching of tobacco issues to medical students.

JEAN FRANÇOIS TESSIER, CHAKIB NEJJARI, DOMINIQUE BELOUGNE Inserm Unité 330 ,

Université de Bordeaux II, Bordeaux, France

DANice THOrdiologie, Groupe Hospitalier la Pitié Salpétrière, Paris PAUL FREOUR

European Medical Association on Smoking and Health (EMASH), Bordeaux

1 Gilpin E, Pierce J, Goodman J, Giovino G, Berry C, Burns D. Trends in physicians' giving advice to stop smoking, United States, 1974-87. Tobacco Control 1992; 1: 31-6.

2 Turner R, Ball K. The cardiologist's responsibility for preventing coronary heart disease. Am Heart F 1976; 91 : 139-47.

3 Wells KB, Lewis CE, Leake B, Scheiter MK, Brook RH. The practices of general and subspecialty internists in counselling about smoking and exercise. Am $\mathcal{F}$ Public Health 1986, 76: 1009-13.

4 Tessier JF, René L, Nejiari C, Belougne, Moulin J, Fréour P. Attitudes and opinions of French general practitioners towards tobacco. Tobacco Control 1993; 2: 226-30.

5 Crofton JW, Fréour P, Tessier JF. Medical education on tobacco: implications of a worldwide survey. Med Educ 1994; 28 : 187-96.

Tobacco "control": a consumerfriendly term?

To the Editor - I continue to be pleased with the high quality and wide variety of articles in Tobacco Control.

As you well know, however, we have an entirely new ball game [in the US] since the Republicans took office, with the significant leaders in Congress being openly beholden to tobacco interests. Consequently, we are going to need to rethink our strategies, particularly looking at ways in which we can reach the average individual in terms that are emotionally meaningful to that person.

I wonder if we should take a serious look at the name of the journal, Tobacco Control? I can tell you, as a psychiatrist, that the last thing anyone wants is to be controlled by any external influence. Although you and I, and most readers of the journal, know that our goal is to control the devastating effects of tobacco consumption, the word "control" is not one likely to make our cause consumerfriendly. Perhaps if we can incorporate the concept that smokers and chewers really have no control over their behaviour and that smoking is a loss of autonomy and empowerment, we might reach people who otherwise would be turned off by the concept of "tobacco control"?

Perhaps we could invite readers to submit proposed new titles for our journal ? Because our articles deal with the deleterious effects of tobacco, perhaps Tobacco Pathology, dealing with problems in the broad sense of the word, might be appropriate. From the standpoint of a psychiatrist, tobacco use is the most maladaptive behaviour that we encounter in both individuals and society, so something like Tobacco Madness or Tobacco Craziness might even be appropriate!

Keep up the good work.

SHELDON B COHEN Atlanta, Georgia, USA

In reply-Thank you for your thoughtful letter. Before we launched Tobacco Control, we solicited suggestions for the name of the journal through networks of people working in the field of tobacco and health. Titles we 
considered included various combinations of the following words: smoking, tobacco, nicotine, journal, international, prevention, cessation, reduction, problems, disease, and health.

We chose Tobacco Control for three main reasons: (a) it reflects our intention to focus on the control of the problem, as opposed to effects of tobacco use on disease processes; (b) it subsumes the major interventions in this area, including public education, prevention, cessation, and policy; and (c) it is pithy, as are the names of other journals published by the BMJ Publishing Group for example, Eye, Gut, and Thorax. In the masthead on the front and back cover of the journal, we have added "An International Journal" as a subtitle to emphasise our goal to include material from throughout the world.

The issue you raise, though, is an important one. "Control" has many meanings. When people hear "tobacco control", do they think of control by government, by a "smoking police", by "smoking Nazis" (a term used recently by a spokesman for Newt Gingrich, Speaker of the US House of Representatives $^{1}$ )? Or do they think of wellintended efforts to reduce tobacco use, appropriate regulation of the manufacture and marketing of tobacco products, or control of behaviour by nicotine?

The Random House Dictionary of the English Language (unabridged edition) provides 16 definitions of "control", one of which is particularly relevant to tobacco control: "prevention of the flourishing or spread of something undesirable: rodent control" (emphasis in original). ${ }^{2}$

"Control" also seems to be an accepted, if not standard, term in public health circles. One of the leading textbooks in public health has included chapters entitled "Communicable disease control", "Occupational and environmental health control", and "Smoking: health effects and control", 3 The US Centers for Disease Control and Prevention has a National Center for Injury Prevention and Control, a Division of Cancer Prevention and Control, and a Measles Control Unit. ${ }^{4}$ A directory of state public health agencies shows "control" in the names of many of their organisational units, including "Radiation Control" (Alabama), "Diabetes Control" (Alaska), "Zoonosis Control" (Colorado), "Tuberculosis Control" (Florida), "Litter Control" and "Vector Control "(Hawaii), "Drug Control" (Maryland/Rhode Island), "AIDS Prevention and Control" (New Jersey), "Environmental Quality Control" and "Air Quality Control" (South Carolina), and "HIV and STD Control" (Texas). ${ }^{5}$

We can speculate about whether the term "tobacco control" helps or hinders our efforts. Or better yet, someone could do a bit of research to see what the term means to consumers, policy makers, and other targets of our work.

RONALD M DAVIS Editor

1 Dowd M. Speaking for House Speaker and enjoying the trappings. New York Times 1995; Jan 5: A1.

2 Random House dictionary of the English language: the unabridged edition. New York Random House, 1967.

3 Last JM, ed. Public health and preventive medicine (Maxcy-Rosenau), 12th ed. Norwalk Connecticut: Appleton-Century-Crofts, 1986.

$4 C D C$ and $A T S D R$ communications directory.
Atlanta, Georgia: Centers for Disease Control and Prevention/Agency for Toxic Substances and Disease Registry, October 1994

5 Association of State and Territorial Health Officials. 1994 Directory of state public healt agencies. Washington, DC: ASTHO, 1994.

\section{Smokers in Marvel Comics}

To the Editor - Marvel Comics has recently received praise from such sources as the New England fournal of Medicine (1994; 330: 1321) and the Columbia fournalism Review (January/February 1995: 20) because they cancelled trading cards showing characters (heroes and villains) smoking. In addition, trade advertisements stating "These Spokespeople will Never Smoke..." (published in Tobacco Control 1994; 3: 199) demonstrate Marvel's commitment to health via communication with kids. Marvel's comic books, however, the major communicator of the company, tell a different story.

A recent survey of the popular $X \mathrm{Men}$ titles, reveals an abundance of characters (the heroes, the role models) smoking. Some of these are established adult characters whose smoking is, unfortunately, part of their persona. "Wolverine", the mutant warrior, can smoke with impunity because he has a "healing factor" which protects him from harm. Teenagers, who consider themselves immune from the health effects of tobacco, will surely be consolled by this character. "Gambit," the Cajun thief, lives for adventure and risk-taking, and smoking enhances the image. Although the behaviour of these characters may be excused because they are adults, recent actions by Marvel have exceeded these limits when they introduced teenage smokers.

The new character of "Skin" is an egregious example of this (figure). $\mathrm{He}$ is a 16 -yearold, extremely ugly Hispanic teenager, insecure about his appearance, who gets by with attitude. Part of this "attitude" is his smoking behaviour. His character sends just the wrong message to teenage readers: if you're upset about your looks and your standing in the world, use tobacco to calm down/project a tough attitude. A recent issue of Generation Next (March 1995) takes this even further. Here we have "Shadowcat", a teenage character who is talented, tough, and beautiful. For no apparent reason (and in a change from her previous characterisation) we see her casually smoking after a fight scene. The message is clear: even respected, dominant teenagers smoke, either to relieve stress or for no reason at all.

Marvel characters are important figures to a huge number of children and youth. There is no reason that these heroes should be modelling dangerous, addictive behaviour to project images of idealised rebellion. I call on Marvel Comics to immediately change this behaviour in their comics as they have done in their trading cards. They owe it to their loyal public.

\section{MICHAEL LIPPMAN Washington DOC Seattle, Washington, USA}

In reply-Marvel Entertainment (including Marvel Comics) is owned by Ron Perelman, a cigar-smoking billionaire who also owns Consolidated Cigar Corporation. Perelman was featured on the cover of the Spring 1995 issue of Cigar Aficionado, which included an in-depth interview with him. - ED

\section{Women and tobacco}

To the Editor-We answered a letter from Deborah McLellan voicing dissatisfaction about the Ninth World Conference resolutions on 21 March 1995. Discovering that the letter has been published in the letters section of Tobacco Control, ${ }^{1}$ I would like to request that our response to her also be published in Tobacco Control. It is unfor-

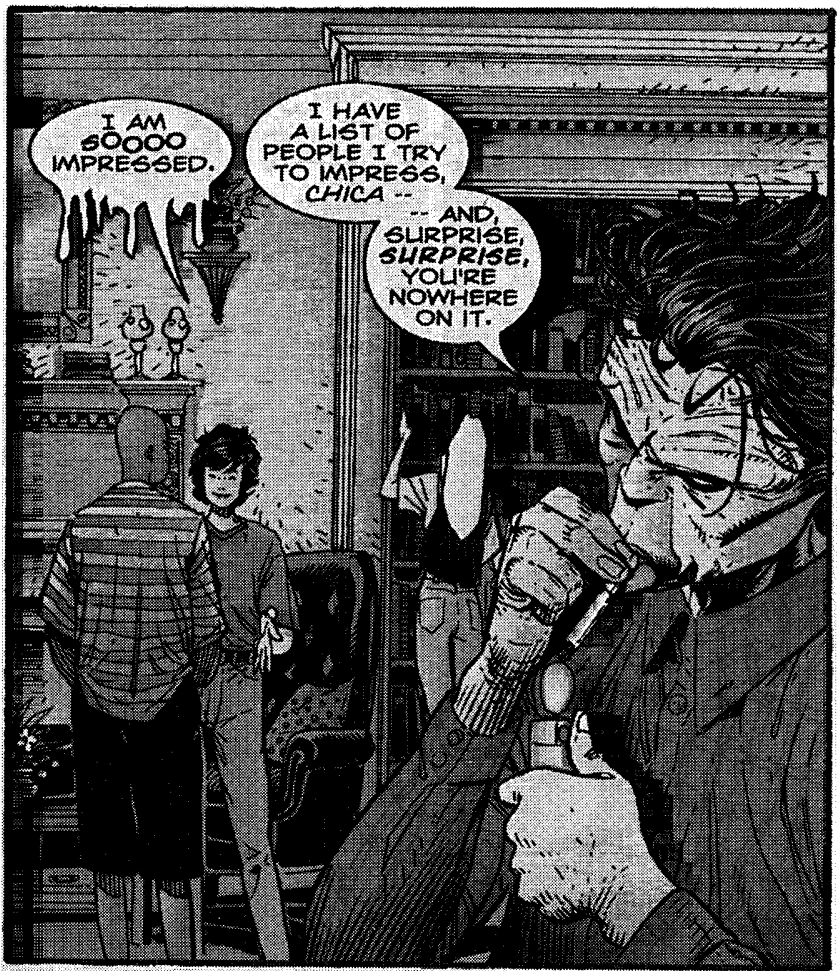

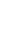

.

.

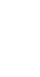

